\title{
The Effectiveness of the Implementation of PjBL Learning Models With a Scientific Approach to Interests and Learning Outcomes in Animal Anatomy and Physiology Materials
}

\author{
Jaharudin', Abdul Rachman Tiro ${ }^{2}$, Budi Santoso ${ }^{3}$, \\ University of Education Muhammadiyah Sorong \\ Jln. KH. Ahmad Dahlan No 1 Mariat Pantai Distrik Aimas Kabupaten Sorong \\ Jaharudin2008@gmail.com, updoelrachman@gmail.com, 92budisantoso@gmail.com
}

\begin{abstract}
This study aims to determine the effectiveness of the application of the Project-Based Learning (PjBL) Model with a Scientific Approach to Interests and Learning Outcomes in Animal Anatomy and Physiology Materials. This research is an experimental study, with a nonequivalent control group design. The population in this study were Biology Education Students, FKIP UNIMUDA Sorong, amounting to 178 people. The sample of this research is the students of Semester V A totaling 21 people as the Experiment class and Semester V B totaling 20 people as the control class. The research instrument used was the lecturer and student activity sheet. Questionnaire of interest in learning and multiple-choice test questions. Results The data obtained in this study were then tested for normality and homogeneity as a prerequisite test for testing the hypothesis. Hypothesis-testing used independent sample t-test and n-gain. The results showed that student learning outcomes using a project-based learning model with a scientific approach the average value of learning outcomes of 79.50 increased by $43.10 \%$ with learning completeness reaching $88.77 \%$ (Effective), compared to classes that did not receive treatment. (control class) the average value of learning outcomes is only 63.39 , an increase of $28.62 \%$ with learning completeness only $42.21 \%$ (Not Effective). Based on the results of data analysis using the t-test, it is known that (1) there is an effect of the ProjectBased Learning learning model with a scientific approach on student interest in learning with a value of tcount $(4,308)>$ t-table $(1,685)$ at a significance level of $5 \%$. (2) there is an effect of the Project-Based Learning learning model with a scientific approach on student learning outcomes with a value of t-count $(3,574)>$ t-table $(1,685)$ at a significance level of $5 \%$.
\end{abstract}

Keyword: PjBL, Scientific Approach, t-test, n-gain

\section{Introduction}

The quality of education, especially in eastern Indonesia, cannot be equated with other education. the improvement of education must always be balanced with existing local wisdom because the Papuan people are unique people who always uphold their local wisdom. Education is a conscious effort to improve human quality both in the cognitive, affective, and psychomotor fields (Anwar, 2020). Meanwhile, education is every association that occurs between adults and children is a field or a situation where the work of educating takes place. Education is one of the functions that must be carried out as well as possible by the family and community in an integrated manner with 
various institutions that are deliberately held to develop the function of education (Kristanti et al., 2016)

Project Based Learning (PJBL) is a learning method that uses projects/activities as media. Learners conduct exploration, assessment, interpretation, synthesis, and information to produce various forms of learning outcomes (Meriani et al., 2019).

Project-Based Learning (PjBL) Learning Model is a learning process that directly involves students to produce a project, basically this learning model develops more solving skills in working on a project that can produce something. In its implementation, according to (Lina listiana, 2011) this model provides broad opportunities for students to make decisions in choosing topics, conducting research, and completing a particular project.

One of the learning models in the 2013 Curriculum that provides opportunities for students to develop problem-solving skills is the project-based learning (PjBL) model or project-based learning model (Kusumaningrum \& Djukri, 2016). Project-based learning provides complex tasks based on challenging questions or problems that involve students in problem-solving, decision making, investigation, and reflection activities involving the teacher as a facilitator (Sastrika et al., 2013).

In its implementation, this model provides broad opportunities for students to make decisions in choosing topics, conducting research, and completing a particular project. Learning by using projects as a learning method. Students work for real as if there is a real-world that can produce products realistically (Sari \& Angreni, 2018).

During this covid-19 era, Learning Innovation through the Project-Based Learning (PjBL) Learning Model with a scientific approach is very relevant to be applied at Muhammadiyah universities in West Papua, one of which is the Muhammadiyah Sorong Education University. With this learning model, it is expected that students will work on projects related to the material being taught and students are given full freedom to choose the projects to be worked on by applying a scientific approach during the project-making process.

Based on the research background, the authors try to research with the theme, namely the Effectiveness of the Implementation of the PjBL Learning Model with a Scientific Approach to Interests and Learning Outcomes in Animal Anatomy and Physiology Materials.

\section{Purpose}

a. To find out the use of Project-Based Learning with a scientific approach in Animal Anatomy and Physiology courses is effective compared to using the lecture learning model.

b. To determine the effectiveness of the application of the PjBL learning model with a scientific approach to interest in learning.

c. To determine the effectiveness of the application of the PjBL learning model with a scientific approach to student learning outcomes.

\section{Method}

This study is a quasi-experimental study to determine the effectiveness of the application of a project-based learning model with a scientific approach to interest and learning outcomes in animal 
anatomy and physiology, in this case, the treatment given by the researcher is the application of a project-based learning model with a scientific approach.

The research design used in this study was the Nonequivalent (Pretest-Posttest) Control Group Design, namely that two groups were selected proportionally. The design of this research can be described as follows:

\begin{tabular}{|lcc|}
\hline $\mathrm{O}_{1}$ & $\mathrm{X}$ & $\mathrm{O}_{2}$ \\
\hline $\mathrm{O}_{3}$ & & $\mathrm{O}_{4}$ \\
\hline
\end{tabular}

\section{Figure 1. Quasi-Experimental Design with Nonequivalent Pretest-Posttest Control Group Design}

Information:

$\mathrm{O} 1$ and $\mathrm{O} 3$ : pretest results before being given treatment

$\mathrm{X} \quad$ : implementation of the PjBL learning model in the experimental class.

$\mathrm{O} 2 \quad$ : the results of the experimental class posttest.

O4 control class posttest results

This research uses the purposive sampling technique. This sampling method is based on the consideration of the researcher, the consideration in question is that in the fifth-semester students' interest and learning outcomes are still low compared to other semesters. The selection of the control class and the experimental class was done by being selected directly by the researcher. The sample in this study involved two classes, namely in Semester V A totaling 21 students acting as an experimental class and Semester V B totaling 20 students acting as a control class with a population of 178 students from Biology education, FKIP Muhammadiyah Education University, Sorong.

The instruments or tools used for data collection in this study were as follows: Questionnaire of student responses to project-based learning and interest in learning and learning outcomes test questions. Sheets of pretest and posttest items in the form of objective questions. Before the questions are given, the students need to be tested. Furthermore, the test trial data were analyzed on: 1) discriminating power, 2) difficulty level, 3) test item validity, and 4) test reliability.

The data analysis technique used in this study used a prerequisite test, namely the normality test using the Kolmogorov-Smirnov test to determine whether the data were normally distributed or not. The homogeneity test aims to determine whether the variance between groups is homogeneous. In addition, the N-Gain Test was conducted to calculate the increase between the initial test and the post-test using the following formula:

$$
N-\text { Gain }=\frac{S_{\text {post }}-S_{\text {pre }}}{S_{\text {maks }}-S_{\text {pre }}}
$$

Information :

Spost : Post-test score 
Spre : Pre-test score

Smax : Ideal maximum score

The criteria for obtaining an $\mathrm{N}$-gain score can be seen in the following table:

Table 3. Criteria for $\mathrm{N}$-gain

\begin{tabular}{ll}
\hline Classification & Category \\
\hline $\mathrm{g} \geq 0,70$ & High \\
$0,30 \leq \mathrm{g}<0,70$ & Medium \\
$\mathrm{g} \leq 0,30$ & Low \\
\hline
\end{tabular}

After the prerequisite test is done, the next step is to test the hypothesis. The hypothesis test used is the parametric statistic t-test of two independent samples (Independent Sample t-test) which aims to determine the effect between the experimental group and the control group.

(Arikunto, 2015) Stating that to find out the effectiveness of learning is carried out on two kinds of things, namely the effectiveness of learning for individuals and the effectiveness of learning for classical.

\section{Results And Discussion}

\section{A. Learning Interest Questionnaire Results Data}

Table 4.1. Pretest Questionnaire of Control and Experimental Class Study Interest

\begin{tabular}{llllll}
\hline Scale & & \multicolumn{2}{l}{ Pretest (Control) } & \multicolumn{2}{l}{ Pretest (Eksperiment) } \\
\hline Range & Category & Frequency & Percent & Frequency & Percent \\
\hline $\mathrm{X}>102$ & Very Good & 0 & $0 \%$ & 0 & $0 \%$ \\
$84<\mathrm{X} \leq$ & Good & 1 & $5 \%$ & 1 & $4,77 \%$ \\
102 & Enough & 17 & $85 \%$ & 18 & $85,71 \%$ \\
$66<\mathrm{X} \leq 84$ & Not Enough & 2 & $10 \%$ & 2 & $9,52 \%$ \\
$48<\mathrm{X} \leq 66$ & Very less & 0 & 0 & 0 & 0 \\
$\mathrm{X} \leq 48$ & & & & & \\
\hline
\end{tabular}

In table 4.1. The pretest questionnaire of interest in learning in the control and experimental classes was not much different in the level scale acquisition. in the sufficient category, the control class is 17 students with a percentage of $85 \%$ and in the experimental class, there are 18 students with a percentage of $85 \%$.

Table 4.2. Posttest Questionnaire of Learning Interest in Control and Experiment Class

\begin{tabular}{llllll}
\hline Scale & & \multicolumn{2}{l}{ Posttest (Control) } & \multicolumn{2}{l}{$\begin{array}{l}\text { Posttest } \\
\text { (Eksperiment) }\end{array}$} \\
\hline Range & Category & $\begin{array}{l}\text { Frequen } \\
\text { cy }\end{array}$ & Percent & $\begin{array}{l}\text { Frenquen } \\
\text { cy }\end{array}$ & Percent \\
\hline $\mathrm{X}>102$ & Very Good & 2 & $10 \%$ & 7 & $33,33 \%$ \\
$84<\mathrm{X} \leq$ & Good & 3 & $15 \%$ & 11 & $52,38 \%$ \\
102 & Enough & 14 & $75 \%$ & 3 & $14,29 \%$ \\
$66<\mathrm{X} \leq 84$ & Not Enough & 0 & 0 & 0 & 0 \\
$48<\mathrm{X} \leq 66$ & Very less & 0 & 0 & 0 & 0 \\
\hline
\end{tabular}


Table 4.2 shows that there are differences in interest in learning in the posttest control and experimental classes treated with PjBL learning models with a scientific approach. In the control class, $75 \%$ of student's interest in learning is in the sufficient category, $15 \%$ of student interest in learning is in a good category and $10 \%$ of student interest in learning is in the very good category. While in the experimental class that received treatment using PjBL with a scientific approach, student learning interest in the very good category reached $33.33 \%$, student interest in learning in the good category, $52.38 \%$ student interest in learning in the moderate category $14.29 \%$. By using the PjBL learning model with a scientific approach, student interest in learning has increased by 7 students who are in the very good category.

\section{B. Hypothesis Test Results}

Test the hypothesis in this study by using the independent sample t-test or commonly called the t-test. The basis for decision making on hypothesis testing if the significant level obtained $>$ 0.05 then $\mathrm{H} 0$ is accepted, whereas if the significance level obtained is $<0.05$ then $\mathrm{H} 1$ is accepted. Following are the results of hypothesis testing;

Table 4.3. t-test Student Learning Interest Questionnaire

\begin{tabular}{llll}
\hline & T & df & Sig. (2 tailed) \\
\hline N-Gain & 4.308 & 39 & .000 \\
\hline
\end{tabular}

Based on table 4.3 Independent sample t-test in the equal variances assumed column through SPSS, a significance of $0.000<0.05$ was obtained. then $\mathrm{H} 0$ is rejected. This shows that there is a significant influence between the PjBL learning model and the scientific approach on student learning interest, in other words, there is an influence between student learning interest given learning through PjBL learning with a scientific approach and conventional learning.

Table 4.4 t-test student learning outcomes

\begin{tabular}{llll}
\hline & T & df & Sig. (2 tailed) \\
\hline N-Gain & 3.754 & 39 & .001 \\
\hline
\end{tabular}

Based on Table 4.4 Independent sample t-test in the equal variances assumed column through SPSS, a significance of $0.001<0.05$ was obtained. then $\mathrm{H} 0$ is rejected. This shows that there is a significant effect between the PjBL model with a scientific approach on student learning 
outcomes, in other words, there is an influence between student learning outcomes given learning through PjBL with a scientific approach and conventional learning.

Based on the calculation of the interest in learning questionnaire data obtained t-count of 4.308 with $\mathrm{df}=\mathrm{n}-2(41-2=39)$ obtained t-table of 1.684. Based on the value data analysis, namely $\mathrm{t}$-count $>\mathrm{t}$-table $(4.308>1.684)$ with a significance level of $0.05(0.000<0.05)$, the hypothesis is accepted, so it can be concluded that there is an effect of applying the PjBL learning model with a scientific approach to interest in learning, while in Hypothesis testing of learning outcomes obtained t-count of 3,754>t-table of 1,684 with a significant level of $0.05(0.001<$ 0.05) then the hypothesis is accepted, so it can be concluded that there is an effect of applying the PjBL learning model with a scientific approach to student learning outcomes in anatomy and material. animal physiology.

\section{N-gain test results}

After conducting the Hypothesis Test, the N-gain test was carried out to determine the extent to which the increase in student interest scores and learning outcomes between before and after the PjBL learning model with a scientific approach was applied by looking for the difference in the posttest and pretest scores.

\section{Discussion}

Based on the results of the study, it was shown that learning using the PjBL learning model with a scientific approach in the experimental class significantly improved student learning outcomes. This can be seen from the comparison of the results of the pretest and posttest of the control class and the experimental class. In the experimental class, the test results after being given learning using the PjBL Learning model with a scientific approach were higher than the test results for the control class using direct learning. This is proven in hypothesis testing using $\mathrm{t}$-test, by comparing $\mathrm{t}$-count with $\mathrm{t}$-table, then the value of $\mathrm{t}$-count $>\mathrm{t}$-table is obtained.

Before the implementation of learning using the PjBL learning model with a scientific approach, the learning process uses a direct learning model which is more dominated by lecturers. Students do not actively participate in all learning activities. After carrying out learning activities using the PjBL learning model with a scientific approach, students are more active in participating in learning, lecturers do not dominate the class, students are also able to learn independently. Activities carried out by the class during the learning process include three kinds of activities, namely preliminary activities, core activities, and closing activities. The implementation of this research was carried out for six meetings including pretest and posttest.

During the implementation of project-based learning, students remain in the task of carrying out tasks that are their responsibility and remain in groups during group work. In addition, in groups students are willing to accept assignments, give trust to friends to complete assignments, and help group friends in completing assignments and actively ask, listen, and contribute during project completion. When learning takes place.

The results of the analysis showed that the increase in the experimental class was better than the control class in the subjects of Animal Anatomy and Physiology. Calculation of the relative increase in the experimental class and the control class can be concluded that the relative 
increase in the experimental class is $41.9 \%$ higher than the control class $27.52 \%$. From the level of mastery learning the experimental class is better than the control class, where after conducting research, the experimental class results from 21 students, 18 of them have completed learning $(85.71 \%$ ) (Effective). Meanwhile, in the control class of 21 students, only 9 students finished studying $(42.85 \%)$ (Not Effective).

\section{Conclusion}

Based on the results of previous research and discussions, it can be concluded that:

1. The use of Project-Based Learning with a scientific approach in Animal Anatomy and Physiology courses is effective compared to using the lecture learning model. ProjectBased Learning with Scientific Approach learning completeness reaches $85.71 \%$ (Effective), while the lecture learning model completes learning only 42.85\% (Ineffective).

2. There is an effect of applying the PjBL learning model with a scientific approach to interest in learning. These results were obtained from hypothesis testing using independent samples $t$-test, the value of t-count $(2,164)>t$-table $(1,684)$ at a significance level of $5 \%$. The results of the N-gain test saw the effect of PjBL learning with a scientific approach on students' interest in learning from the average $\mathrm{N}$-gain value of $0.44 \%$ where the value was in the medium category.

3. There is an effect of applying the PjBL learning model with a scientific approach to student learning outcomes. These results were obtained from hypothesis testing using independent samples t-test, the value of t-count $(2,688)>t$-table $(1,684)$ at a significance level of $5 \%$. The results of the $\mathrm{N}$-gain test see the effect of the PjBL learning model with a scientific approach on student learning outcomes from the average $\mathrm{N}$-gain value of $0.55 \%$ where the value is in the medium category.

\section{References}

Anwar, A. S. (2020). Pengembangan Sikap Profesionalisme Guru Melalui Kinerja Guru Pada Satuan Pendidikan Mts Negeri 1 Serang. Andragogi: Jurnal Pendidikan Islam Dan Manajemen Pendidikan Islam, 2(1), 147-173. https://doi.org/10.36671/andragogi.v2i1.79

Kristanti, Y., Subiki, S., \& Handayani, R. (2016). Model Pembelajaran Berbasis Proyek (Project Based Learning Model) Pada Pembelajaran Fisika Di SMA. Jurnal Pembelajaran Fisika Universitas Jember, 5(2), 116319.

Kusumaningrum, S., \& Djukri, D. (2016). Pengembangan perangkat pembelajaran model project based learning $(\mathrm{PjBL})$ untuk meningkatkan keterampilan proses sains dan kreativitas. Jurnal Inovasi Pendidikan IPA, 2(2), 241. https://doi.org/10.21831/jipi.v2i2.5557

Lina listiana. (2011). Pemberdayaan Keterampilan Berpikir Dalam Pembelajaran Biologi Melalui Model Kooperatif Tipe Gi (Group Investigation) Dan Ttw (Think, Talk, Write). Jurnal, 2, 1-7.

Meriani, M., Khairil, K., \& Kasmirufdin. (2019). ... Berpikir Kritis Siswa dalam Penerapan Model Pembelajaran Problem Based Learning (PBL) dan Project Based Learning (PjBL) Pada Pembelajaran Biologi di SMA .... Seminar Nasional Sains ..., 1-9.

Sari, R. T., \& Angreni, S. (2018). Penerapan Model Pembelajaran Project Based Learning (PjBL) Upaya Peningkatan Kreativitas Mahasiswa. Jurnal VARIDIKA, 30(1), 79-83. https://doi.org/10.23917/varidika.v30i1.6548

Sastrika, I. A. K., Sadia, I. W., \& Muderawan, I. W. (2013). Pengaruh model pembelajaran berbasis proyek 
terhadap pemahaman konsep kimia dan keterampilan berpikir kritis. E-Journal Program Pascasarjana Universitas Pendidikan Ganesha, 3(2), 194-204.

\section{Biography}

Jaharudin was born in wawo on May 02, 1990. He completed his undergraduate education in Biology Education at Alauddin Makkassar State Islamic University in 2012, then continued his master's program in Biology Education at Makassar State University 2016. And now serves at the Muhammadiyah Education University of Sorong as a permanent lecturer.

Abdul Rachman Tiro was born in Sentani, Jayapura Regency-Papua on November 1, 1987. He completed his undergraduate education in the chemical education study program at Cenderawasih University in 2011. Kmd he continued his master's program at the same campus in the Science Education Study Program, graduating in 2014. Currently he became a permanent lecturer at Unimuda Sorong.

Budi Sntoso was born in Wonogiri on February 6, 1992. He completed his bachelor's degree in Islamic religious education at the Muhammadiyah University of Ponorogo in 2014. Then he continued his master's program at the same campus when he graduated in 2016. He is currently a permanent lecturer at Unimuda push. 